\title{
Effect of soil moisture on the ability of Italian rye grass (Lolium multiflorum Lam.) to reduce an injurious content of nitrate nitrogen in soil.
}

\author{
ANTTI JAAKKOLA ${ }^{1}$ ) \\ University of Helsinki, Department of Agricultural Chemistry
}

\begin{abstract}
The ability of Italian rye grass (Lolium multiflorum) to reduce a high content of mineral nitrogen in soil was studied in a pot experiment in greenhouse. The experimental soil consisted of a silty clay rich in humus and a fine sand. The soils were kept at three moisture levels corresponding approximately to $\mathrm{pF}$ values 2,3 and 4 . Two levels of nitrogen were applied, 175 and $350 \mathrm{mg} / \mathrm{kg}$, as ammonium nitrate. The clay and fine sand soils initially contained 370 and $780 \mathrm{mg} / \mathrm{kg}$ of nitrate nitrogen, respectively. The grass was harvested five times during 205 days.

The excess of the nitrate in the clay soil prouducing high nitrate contents in the grass was exhausted after two cuttings when the soil moisture was kept at pF 2, whereas it was not reduced at all at $\mathrm{pF} 4$. At $\mathrm{pF} 3$, the excess nitrate was exhausted after the 3rd and 4th cutting at lower and higher nitrogen application levels, respectively.

The nitrate content of the grass grown on the fine sand soil was reduced to an acceptable level only at pF 2 and after the lower application of nitrogen, not before the last cutting. however.
\end{abstract}

Inorganic, mostly ammonium or nitrate nitrogen can be readily taken up by plants. The plant tolerates in its tissue only very low contents of ammonium nitrogen. In practice there is not usually so much ammonium in soil that the uptake would exceed the ability of the plant to utilize it. A dangerously high content of nitrate nitrogen in soil is more common. At a high soil nitrate level the crop may contain so much nitrate that it cannot be used as human food or animal fodder. The plants themselves tolerate relatively high contents of nitrate in their tissues, but only a fraction of it may prevent the utilization of the crop products. Moreover, nitrate nitrogen in soil is readily leached causing a pollution risk to ground water in addition to the direct loss of a part of the nutrient.

The aim of this study was to investigate how fast the injuriously high content of nitrate nitrogen in soil is reduced by growing Italian rye grass (Lolium multiflorum) in pots, and how it is affected by different levels of soil moisture and mineral nitrogen content.

1) Present address: Agricultural Research Centre, Department of Agricultural Chemistry and Physics, Tikkurila. 
The two experimental soils had the following properties:

\begin{tabular}{|c|c|c|}
\hline & Soil 1 & Soil 2 \\
\hline $\mathrm{pHCaCl}_{2}$. & 5.5 & 6.0 \\
\hline org. $\mathrm{C} \%$ & 10.5 & 4.1 \\
\hline clay content $(<2 \mu \mathrm{m}) \%$ & 46 & 12 \\
\hline $\mathrm{NH}_{4}-\mathrm{N} \mathrm{mg} / \mathrm{kg}$ & 27 & 3 \\
\hline 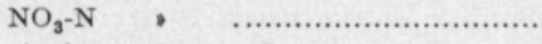 & 370 & 780 \\
\hline air dry moisture $\mathrm{g} / \mathrm{kg} \ldots \ldots \ldots \ldots \ldots \ldots \ldots$ & 48 & 26 \\
\hline
\end{tabular}

Both soils had a very high content of nitrate. The largest part of it originated, no doubt, from the calcium nitrate applied to the soils earlier when they were used in pot experiments.

$800 \mathrm{~g}$ of soil was weighed in plastic pots, 1.31 by volume. The experimental design was as follows:

F a ctor M: soil moisture

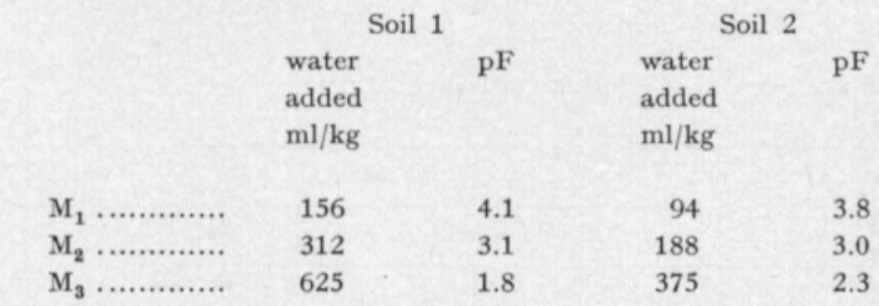

$\mathrm{F}$ a ctor $\mathrm{N}$ : nitrogen application as ammonium nitrate

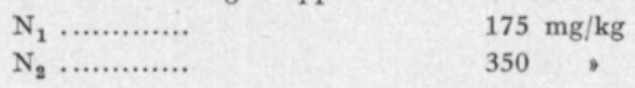

There were four replicates. The basal dressing (K, P, S, Ca, Mg, Cu, Mn, $\mathrm{Zn}$ and $\mathrm{B}$ ) as well as the nitrogen application were added in water solution and mixed thoroughly with the soil. The pots were planted on May 10th 1972 allotting 20 seed of Italian rye grass (Lolium multiflorum) for every pot. The pots were watered after periods of one or two days to the moisture level fixed in the experimental design. The grass was cut five times:

\begin{tabular}{|c|c|c|c|}
\hline Cutting & Date & $\begin{array}{l}\text { Time from } \\
\text { last cutting. } \\
\text { days }\end{array}$ & $\begin{array}{c}\text { Time from } \\
\text { planting, } \\
\text { days }\end{array}$ \\
\hline 1st & 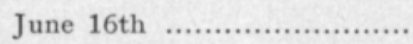 & 37 & 37 \\
\hline 2nd & 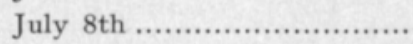 & 22 & 59 \\
\hline $3 \mathrm{rd}$ & 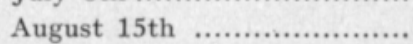 & 38 & 97 \\
\hline 4th & 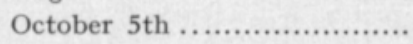 & 56 & 153 \\
\hline 5 th & November 29 th ....................... & 52 & 205 \\
\hline
\end{tabular}

The experiment was carried out in greenhouse. An attempt was made to keep the temperature at $20^{\circ} \mathrm{C}$, but it appeared impossible to prevent a rise in temperature on warm days. The highest temperatures measured were 
not less than $30^{\circ} \mathrm{C}$. Such rises took place between the first and third cuttings, though only occasionally. The light was obviously deficient at the end of the experiment. The plant was cut the first three times at an earlier stage of development than in the last two cuttings when the ear had just emerged.

The yields were dried at $80^{\circ} \mathrm{C}$. They were ground and the total and the nitrate nitrogen were determined. The nitrate nitrogen was determined in a water extract of the plant material by means of a nitrate ion selective electrode. The content of total nitrogen was determined by the common Kjeldahl method modified to include also nitrate nitrogen in the result. After the last cutting the ammonium and nitrate nitrogen in the soil were determined in $0.5 \mathrm{~N} \mathrm{~K}_{2} \mathrm{SO}_{4}$ extracts ( $10 \mathrm{~g}$ of soil per $100 \mathrm{ml}$ of extractant, time $1 \mathrm{~h}$ ) by means of ammonia and nitrate selective electrodes, respectively. The soil $\mathrm{pH}$ was measured in $0.01 \mathrm{M} \mathrm{CaCl}_{2}$ (ratio 1: 2.5).

\section{Results and discussion}

Grass yields

Table 1. Yields of rye grass in $\mathrm{g}$ of D.M. per $\mathrm{kg}$ of soil.

\begin{tabular}{|c|c|c|c|c|c|c|c|c|}
\hline & & & \multicolumn{5}{|c|}{ Cutting } & \multirow[b]{2}{*}{ Total } \\
\hline & & & 1 st & 2nd & 3rd & 4 th & 5 th & \\
\hline \multirow[t]{6}{*}{ Soil 1, } & $\mathrm{M}_{1} \mathrm{~N}_{1}$ & ……................... & $0.11^{\mathrm{a}}$ & $0.33^{\mathrm{a}}$ & $0.90^{\mathrm{a}}$ & $0.65^{\mathrm{a}}$ & $0.56^{\mathrm{a}}$ & $2.55^{\mathrm{a}}$ \\
\hline & $\mathrm{N}_{2}$ & 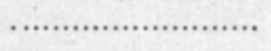 & $0.15^{\mathrm{a}}$ & $0.36^{\mathrm{a}}$ & $0.99^{\mathrm{a}}$ & $0.84^{\mathrm{a}}$ & $0.58^{\mathrm{a}}$ & $2.92^{\mathrm{a}}$ \\
\hline & $\mathrm{M}_{2} \mathrm{~N}_{1}$ & (n....................... & $1.19^{\mathrm{ab}}$ & $2.93^{b}$ & $4.71^{b}$ & $3.58^{\mathrm{c}}$ & $1.29^{b c}$ & $13.70^{b}$ \\
\hline & $\mathrm{N}_{2}$ & (n........................ & $1.56^{\mathrm{ab}}$ & $2.91^{b}$ & $5.00^{\mathrm{b}}$ & $4.37^{d}$ & $1.89^{d}$ & $15.73^{b c}$ \\
\hline & $\mathrm{M}_{3} \mathrm{~N}_{1}$ & $\cdots$ & $2.54^{b}$ & $4.85^{c}$ & $4.16^{b}$ & $2.61^{b}$ & $1.13^{\mathrm{abc}}$ & $15.29^{b c}$ \\
\hline & $\mathrm{N}_{2}$ & 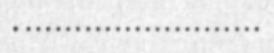 & $2.20^{\mathrm{b}}$ & $5.22^{\mathrm{c}}$ & $5.37^{\mathrm{b}}$ & $3.06^{\mathrm{bc}}$ & $1.66^{\mathrm{cd}}$ & $17.51^{c}$ \\
\hline \multirow[t]{6}{*}{ Soil 2, } & $\mathrm{M}_{1} \mathrm{~N}_{1}$ & ……………… & $0.01^{\mathrm{a}}$ & $0.03^{\mathrm{a}}$ & $0.11^{\mathrm{a}}$ & $0.10^{\mathrm{a}}$ & $0.10^{\mathrm{a}}$ & $0.35^{\mathrm{a}}$ \\
\hline & $\mathrm{N}_{2}$ & 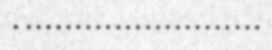 & $0.01^{\mathrm{a}}$ & $0.00^{\mathrm{a}}$ & $0.05^{a}$ & $0.09^{\mathrm{a}}$ & $0.13^{\mathrm{a}}$ & $0.28^{\mathrm{a}}$ \\
\hline & $\mathrm{M}_{2} \mathrm{~N}_{1}$ & .......................... & $0.32^{\mathrm{a}}$ & $0.93^{\mathrm{a}}$ & $2.47^{b}$ & $3.58^{b}$ & $2.42^{b}$ & $9.72^{c}$ \\
\hline & $\mathrm{N}_{2}$ & 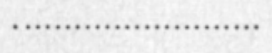 & $0.11^{\mathrm{a}}$ & $0.34^{a}$ & $0.57^{a}$ & $0.76^{a}$ & $0.42^{\mathrm{a}}$ & $2.20^{\mathrm{b}}$ \\
\hline & $\mathrm{M}_{3} \mathrm{~N}_{1}$ & 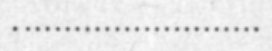 & $0.87^{b}$ & $2.98^{b}$ & $7.09^{d}$ & $6.07^{c}$ & $2.14^{b}$ & $19.15^{d}$ \\
\hline & $\mathrm{N}_{2}$ & n..................... & $0.71^{b}$ & $2.49^{b}$ & $5.72^{\mathrm{c}}$ & $6.38^{c}$ & $2.90^{\mathrm{C}}$ & $18.20^{\mathrm{d}}$ \\
\hline $\mathrm{LSD}_{0.05}$ & 5 betwe & een soils ................ & 1.10 & 1.00 & 1.51 & 1.33 & 0.65 & 2.22 \\
\hline
\end{tabular}

Yields of the same soil and the same cutting not marked by a common letter differ significantly $(\mathrm{P}=0.05)$.

In the dry $\left(M_{1}\right)$ soils the growth of grass was poor (Table 1$)$, this was so especially in soil 2. This is to a certain extent surprising, because the water at the moisture level the soil was watered to was not as firmly bound in the 
soil ( $\mathrm{pF}$ 3.8) as in the other soil ( $\mathrm{pF} 4.1$ ). Obviously the greater content of clay and humus in the latter one, leads to a greater store of available water.

In soil 1 there was enough water at level $\mathrm{M}_{2}$ to produce as large an total yield as at the highest moisture level $\left(\mathrm{M}_{3}\right)$. However, the rhythm of growth was different at these moisture levels. At the second cutting the yield in the moister soil was bigger, while later, at the fourth cutting, the situation was reversed. Apparently the plant needed at the beginning of its growth more water than later. This may depend on the stage of development as well as on external factors, such as the rising temperature which again increased transpiration. The smaller yield in the moister soil at the fourth cutting may be caused by the exhaustion of nutrients. Although it cannot be proved in the light of the results that the main reason was a reduction in the nitrogen content, the change in the total nitrogen content of the plant (Table 2) can be considered as an indication. In fact, the difference in the uptake of nitrogen up to the third cutting (Table 4) does not explain the expected difference in the nitrogen status of the soil. On the other hand it is apparent that the nitrogen losses, probably caused by denitrification, were at moisture level $\mathrm{M}_{3}$ bigger than at level $\mathrm{M}_{2}$ (cf. Table 5).

The growth of rye grass in soil 1 was not usually significantly influenced by raising the nitrogen application from level $\mathrm{N}_{1}$ to level $\mathrm{N}_{2}$. Only at moisture level $\mathrm{M}_{2}$ was there an increase in yield at the last two cuttings. Apparently the soil contained at the beginning of the experiment so much nitrogen available to the plant that additional nitrogen made no difference. Later, as available nitrogen in the soil decreased, the plant benefited from the additional nitrogen. The significant increase in growth, particularly at moisture level $\mathrm{M}_{2}$ may have been a mere chance, but it can be assumed that at a higher moisture level the ability of the plant to take up nitrogen was so much better that the additional nitrogen was exhausted approximately at the same time as the initial plant-available nitrogen in the soil.

In soil 2 the plant grew best at the highest moisture level $\left(\mathrm{M}_{3}\right)$, though at the last cutting, at nitrogen level $\mathrm{N}_{1}$, the harvested yield was at level $\mathrm{M}_{2}$ as large as at level $\mathrm{M}_{3}$. At this time of the year the light may have been a growth limiting factor, but it is also possible that a state of nitrogen deficiency had developed (cf. Table 5). At moisture level $\mathrm{M}_{3}$, the rye grass grew especially well between the second and the third cutting. The growth was very clearly superior to that taking place in soil $\mathbf{1}$ at the same time. Apparently the mineral nitrogen content of soil 2 at the second cutting was reduced by the uptake of the plant to a level no longer detrimental to it, while the plant in soil 1 may have suffered from a nitrogen deficiency.

Raising the nitrogen application from level $\mathrm{N}_{1}$ to level $\mathrm{N}_{2}$ produced in soil 2 at moisture level $\mathrm{M}_{2}$ a clear decrease in growth. This was obviously caused by the high mineral nitrogen content of the soil which showed no decrease during the experiment (Table 5). Increasing the soil moisture reduced the injury caused by too high a content of mineral nitrogen in the soil. There was the same tendency at moisture level $\mathrm{M}_{3}$ at the beginning, but no longer after the third cutting. The last yield benefited by the additional nitrogen. 
Table 2. Total nitrogen contents of rye grass in $\mathrm{mg}$ per $\mathrm{g}$ of D.M.

\begin{tabular}{|c|c|c|c|c|c|}
\hline & \multicolumn{5}{|c|}{ Cutting } \\
\hline & 1st & 2nd & 3rd & 4th & 5 th \\
\hline Soil $1, \mathrm{M}_{1} \mathrm{~N}_{1} \ldots \ldots \ldots \ldots \ldots$ & - & $66.8^{\mathrm{d}}$ & $53.2^{\mathrm{bc}}$ & $56.6^{\mathrm{d}}$ & $55.7^{\mathrm{c}}$ \\
\hline $\mathrm{N}_{2} \ldots \ldots \ldots \ldots \ldots$ & - & $65.7^{\mathrm{d}}$ & $62.2^{\mathrm{c}}$ & $55.0^{\mathrm{d}}$ & $53.7^{\mathrm{c}}$ \\
\hline $\mathrm{M}_{2} \mathrm{~N}_{1} \ldots \ldots \ldots \ldots \ldots$ & $64.1^{\mathrm{b}}$ & $57.1^{\mathrm{c}}$ & $43.8^{\mathrm{b}}$ & $22.7^{\mathrm{b}}$ & $21.0^{\mathrm{a}}$ \\
\hline $\mathrm{N}_{2}$ & $66.7^{\mathrm{b}}$ & $61.6^{\mathrm{cd}}$ & $51.4^{\mathrm{b}}$ & $32.8^{\mathrm{c}}$ & $25.9^{\mathrm{b}}$ \\
\hline $\mathrm{M}_{3} \mathrm{~N}_{1} \ldots \ldots \ldots \ldots \ldots$ & $58.7^{\mathrm{a}}$ & $39.3^{\mathrm{a}}$ & $19.1^{\mathrm{a}}$ & $14.8^{\mathrm{a}}$ & $26.2^{\mathrm{b}}$ \\
\hline $\mathrm{N}_{2} \ldots \ldots \ldots \ldots \ldots$ & $58.0^{\mathrm{a}}$ & $48.6^{\mathrm{b}}$ & $19.4^{\mathrm{a}}$ & $16.1^{\mathrm{ab}}$ & $23.7^{\mathrm{ab}}$ \\
\hline Soil $2, \mathrm{M}_{1} \mathrm{~N}_{1} \ldots \ldots \ldots \ldots \ldots$ & - & - & - & - & - \\
\hline $\mathrm{N}_{2} \ldots \ldots \ldots \ldots \ldots$ & - & - & - & - & - \\
\hline $\mathrm{M}_{2} \mathrm{~N}_{1}$ & $68.7^{\mathrm{b}}$ & $58.2^{\mathrm{a}}$ & $56.8^{\mathrm{a}}$ & $49.2^{\mathrm{bc}}$ & $59.3^{\mathrm{b}}$ \\
\hline $\mathrm{N}_{2} \ldots \ldots \ldots \ldots \ldots$ & $79.0^{c}$ & $67.5^{\mathrm{b}}$ & $67.1^{\mathrm{b}}$ & $56.3^{\mathrm{c}}$ & $64.5^{\mathrm{b}}$ \\
\hline $\mathrm{M}_{3} \mathrm{~N}_{1} \ldots \ldots \ldots \ldots \ldots$ & $66.2^{\mathrm{a}}$ & $58.5^{\mathrm{a}}$ & $50.5^{\mathrm{a}}$ & $30.7^{\mathrm{a}}$ & $27.5^{\mathrm{a}}$ \\
\hline $\mathrm{N}_{2} \ldots \ldots \ldots \ldots$ & $69.7^{\mathrm{b}}$ & $59.5^{\mathrm{a}}$ & $51.6^{\mathrm{a}}$ & $42.8^{b}$ & $37.3^{\mathrm{a}}$ \\
\hline LSD $_{0.05}$ between soils ....... & 3.2 & 5.2 & 8.1 & 9.7 & 8.9 \\
\hline
\end{tabular}

Nitrogen contents of the same soil and the same cutting not marked with a common letter differ significantly $(\mathrm{P}=0.05)$.

The total nitrogen content of rye grass in soil 1 seems clearly to decrease at each cutting (Table 2, statistical testing was not carried out in this direction), except at moisture level $M_{1}$. At moisture level $M_{2}$ the decrease in the total nitrogen of the plant after the third cutting was clear. At the highest moisture level $\left(\mathrm{M}_{3}\right)$ the first decrease took place already after the first cutting, but a clear decrease only after the following cutting. The increasing effect of additional nitrogen on the total nitrogen content of the plant could be detected when the nitrogen content was reduced from its initial level. Apparently the total nitrogen content of the plant was close to the highest level that was possible in the conditions of the experiment. The availability of nitrogen in soil 1 at the highest moisture level $\left(\mathrm{M}_{3}\right)$ was obviously reduced in the $\mathrm{N}_{2}$ treatment to the same level as in the $\mathrm{N}_{1}$ treatment making the soil nitrogen-deficient. A proof of the deficiency is the inability of this soil to produce as high a growth as soil 2 at the same time and at a corresponding level of soil moisture. Apparently the plant took up after the second cutting from soil 1 at the highest moisture level only the nitrogen that had been mobilized from the reserves of organic nitrogen of the soil.

In soil 2 the total nitrogen content of the plant decreased to the lowest level observed in soil 1 only in treatment $\mathrm{M}_{3} \mathrm{~N}_{1}$ and at the last harvest. On the ground of the mineral nitrogen contents determined in the soil after the 
last cutting (Table 5) it is obvious that only in this case had the initial reserves of mineral nitrogen come to an end.

The total nitrogen content of the fourth yield harvested in soil 2 at the highest moisture level responded to additional nitrogen, which can be taken as evidence that the mineral nitrogen content of the soil had dropped to a moderate level. Additional nitrogen no longer reduced the growth. In this soil at moisture $\mathrm{M}_{2}$ there was a tendency of additional nitrogen to increase the total nitrogen content of the plant. This was the case at no other time when there was much mineral nitrogen left in the soil. Thus, increasing the nitrogen application has hardly caused directly the increase in the nitrogen content of the plant. This may be regarded as evidence of poor growth caused by excessive nitrogen in soil. As stated earlier, an additional application of nitrogen was followed by reduction in growth (Table 1).

\section{Nitrate nitrogen contents}

Table 3. Nitrate nitrogen contents of rye grass in $\mathrm{mg}$ per $\mathrm{g}$ of D.M.

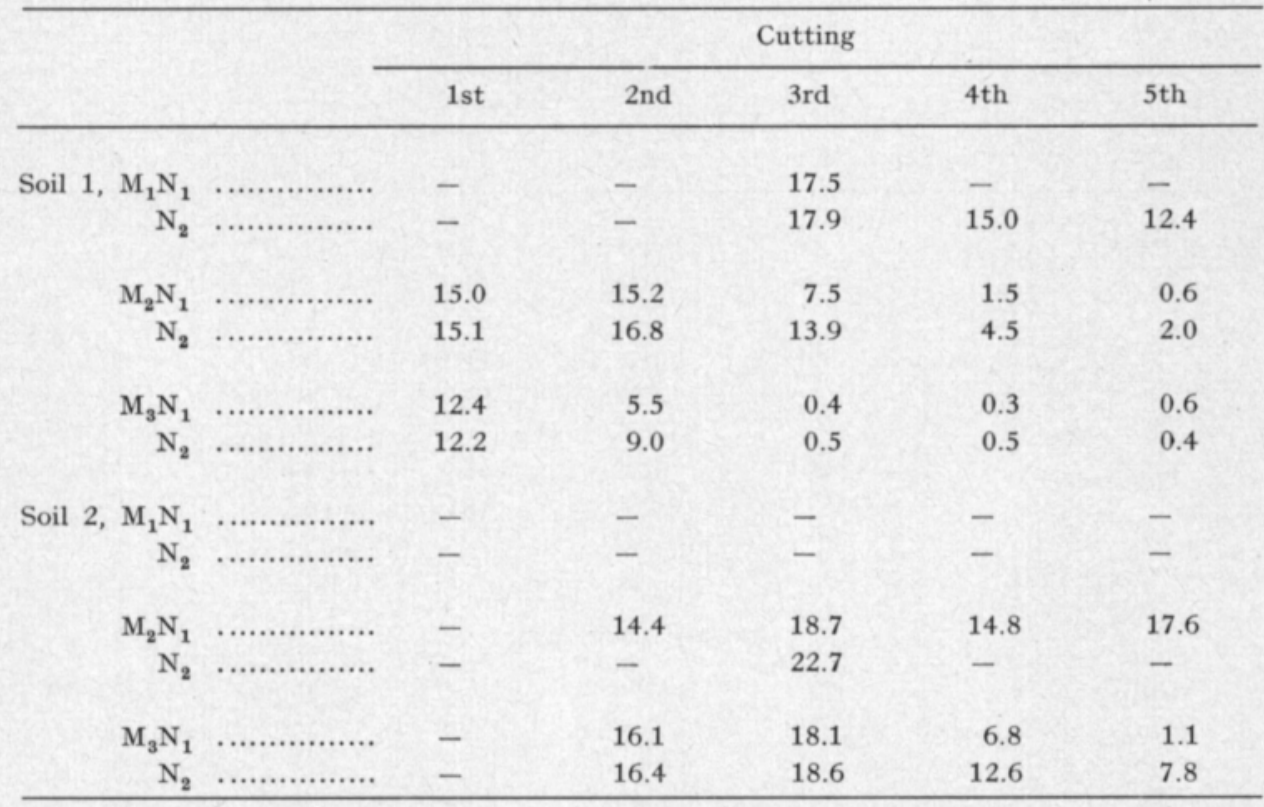

Table 3 is not complete, because some experimental yields were so small that no material could be taken for a determination of nitrate nitrogen, consequently statistical testing could not be carried out. The important differences are so clear, however, that the risk of an error is small, although it can not be determined precisely.

The nitrate nitrogen and the total nitrogen contents of the plant correlated rather closely, calculated from values in Tables 2 and $3, r=0.94 * * *$. This is natural since an increase of the nitrogen uptake over the utilizability of the plant leads to an accumulation of nitrate in the plant material (cf. LAWRENCE et al. 1968). Although a plant tolerates rather high contents of nitrate, relatively 
low contents are detrimental to animals using the plant as fodder. Investigators hold different opinions over the highest tolerable nitrate nitrogen content of animal fodder. For the following discussion it is assumed to be $2 \mathrm{mg} / \mathrm{g}$, a value adopted by LAWRENCE et al. (1968).

In soil 1 , the nitrate nitrogen content of the grass had dropped below the expected limit of toxicity clearly only at the highest moisture level. The drop seems to have taken place after the second cutting. At moisture level $\mathrm{M}_{2}$ the same soil produced toxic fodder for a much longer time; at level $\mathrm{N}_{1}$ to the third, at level $\mathrm{N}_{2}$ to the fourth cutting. The nitrate content of rye grass grown in soil 2 was reduced only in the treatment $\mathrm{M}_{3} \mathrm{~N}_{1}$, and not until the last yield, below the toxic level. The deficiency of light at the end of the experiment may have caused a slight increase in the nitrate nitrogen content of the last yield (cf. CANTLIFFE 1973).

\section{Nitrogen uptake}

Table 4. Cumulative uptake of total nitrogen by rye grass in different cuttings in $\mathrm{mg}$ of nitrogen per $\mathrm{kg}$ of soil.

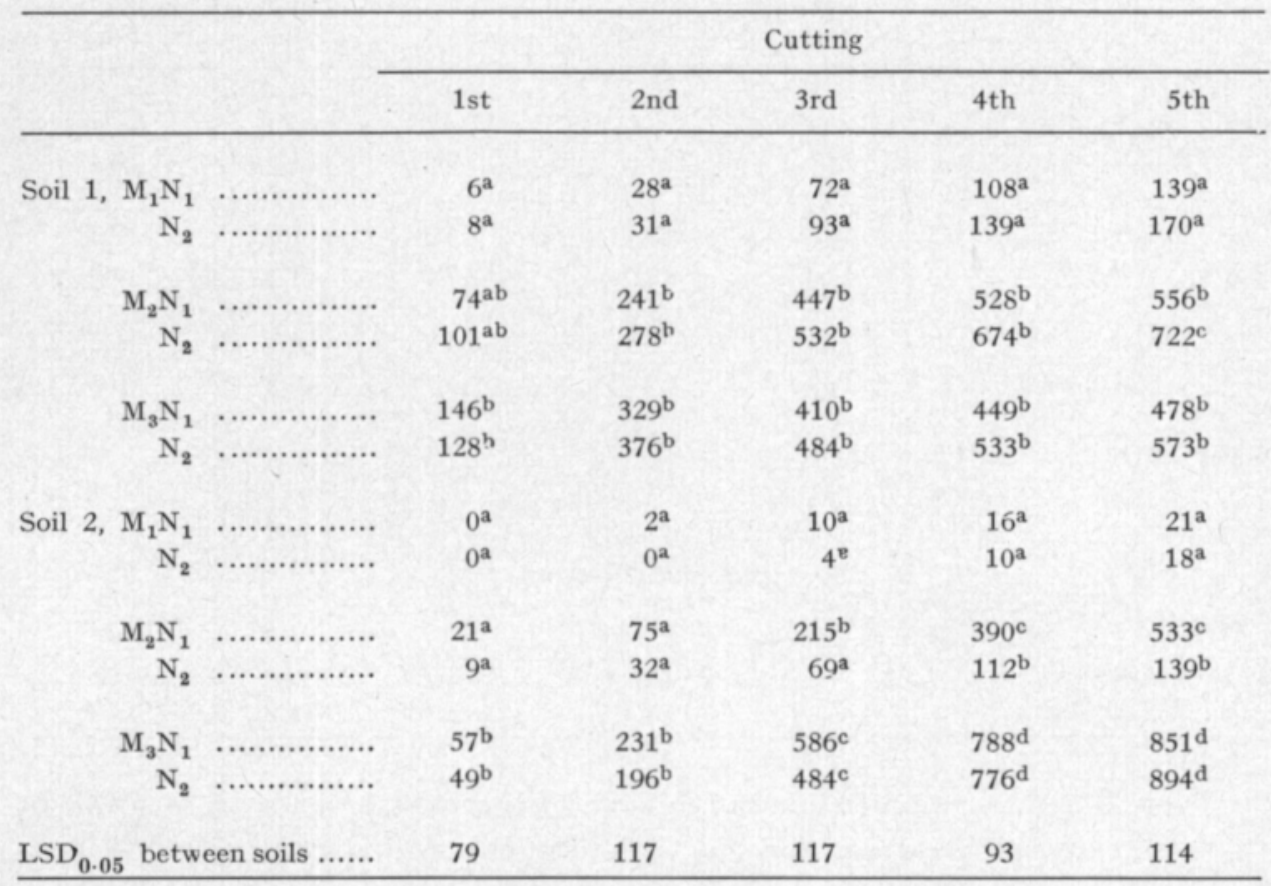

Nitrogen uptakes of the same soil and the same cutting not marked with a common letter differ significantly $(\mathrm{P}=0.05)$.

The uptake of total nitrogen from soil 1 (Table 4) was apparently until the second cut somewhat higher at moisture level $\mathrm{M}_{3}$ than at $\mathrm{M}_{2}$, but the difference was not statistically significant. After this time the uptake from the moistest soil became clearly slower. The reason for this may have been the 
exhaustion of the initial abundant supply of mineral nitrogen, which was assumed on the ground of reduced yields and their total nitrogen contents. At moisture $\mathrm{M}_{2}$ the nitrogen uptake continued to be rather abundant even after the second cut. The total uptake of nitrogen until the end of the experiment seems to have been even more abundant than at the higher moisture level, but the difference was significant only at level $\mathrm{N}_{2}$. The small addition of nitrogen from level $\mathrm{N}_{1}$ to level $\mathrm{N}_{2}$ as compared with the abundant initial mineral nitrogen supply of the soil increased significantly the nitrogen uptake of rye grass only at moisture level $\mathrm{M}_{2}$, but not until the third cut, and the tendency was similar in the other cases.

At the lowest moisture level $\left(\mathrm{M}_{1}\right)$ soil 2 gave to the plant very little nitrogen indeed, due to the extremely poor growth of the grass (cf. Table 1). The moisture level, $\mathrm{M}_{2}$, was not yet sufficient to enable the plant to take up nitrogen effectively. At moisture level $\mathrm{M}_{3}$ the uptake was more effective in all stages studied. The addition of mineral nitrogen to the soil caused a clear decrease in the nitrogen uptake at moisture $\mathrm{M}_{2}$. These differences depend on the differences in growth (Table 1), which are relatively big compared with the differences in the nitrogen contents (Table 2). As stated above, the mineral nitrogen content of the soil at moisture $\mathrm{M}_{2}$ was too high for sufficient growth. As an increase of moisture diminished this disadvantace, one may assume that the injury was caused by too high a concentration of mineral and nitrate nitrogen in the soil solution.

Nitrogen status in soil

At the end of the experiment both soils that had been kept dry $\left(\mathrm{M}_{1}\right)$ contained still a lot of mineral nitrogen (Table 5). In fact no significant reduction in the nitrogen content had taken place. The nitrification seems to have been rather low, too. The content of ammonium nitrogen had not changed during the experiment. In soil 1 , increasing the moisture to the level $\mathrm{M}_{2}$ caused a clear decrease of mineral nitrogen in the soil. It is apparent that by increasing the moisture further to level $\mathrm{M}_{3}$ the reduction in the mineral nitrogen content was made even greater. However, the difference was not statistically singificant in the applied test, the accuracy of which was much reduced by the great variation observed in treatment $\mathrm{M}_{1}$. Increasing the moisture in soil 2 from level $M_{1}$ to $M_{2}$ caused a significant decrease of mineral nitrogen at level $N_{1}$ but not at level $\mathrm{N}_{2}$. Increasing the moisture further to level $\mathrm{M}_{3}$, almost exhausted the mineral nitrogen in soil. There was no difference between levels $\mathrm{N}_{1}$ and $\mathrm{N}_{2}$.

At the higher moisture levels $\left(\mathrm{M}_{2}\right.$ and $\left.\mathrm{M}_{3}\right)$ both experimental soils contained considerably less ammonium nitrogen at the end af the experiment than at the lowest moisture $\left(\mathrm{M}_{1}\right)$. The decrease of ammonium may have been caused both by nitrification and uptake by plant. In soil 2 , in treatment $\mathrm{M}_{2} \mathrm{~N}_{2}$, where the nitrate content of the soil was clearly too high for sufficient growth, the decrease of ammonium does not seem to have slowed down. Obviously the nitrification took place effectively, because the nitrate content of the soil 
Table 5. Nitrogen status and $\mathrm{pH}$ in soils at the end of the experiment.

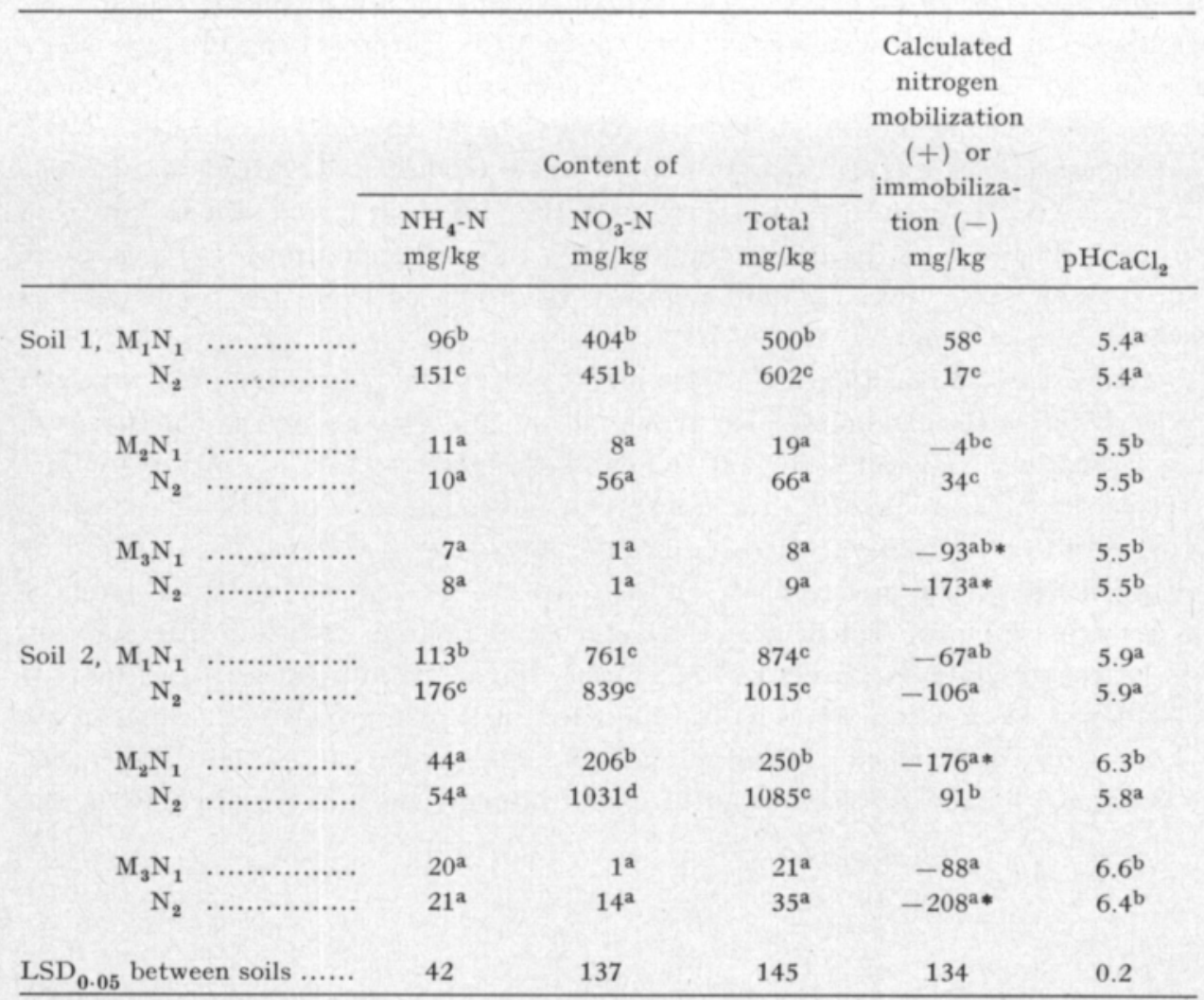

Values of the same soil and the same cutting not marked with a common letter differ significantly $(\mathrm{P}=0.05)$.

* Value deviates significantly $(\mathrm{P}=0.01)$ from zero.

even increased during the experiment in spite of the nitrate uptake by the plant.

The amounts of mobilized and immobilized nitrogen (Table 5) have been calculated by subtraction of mineral nitrogen at the beginning from the sum of soil mineral nitrogen and total nitrogen taken up by plant at the end of the experiment. The nitrogen contained in the roots was not determined as it was considered to be immobilized. The temperature in the greenhouse during the experiment $\left(\geqq 20^{\circ} \mathrm{C}\right)$ was rather beneficial for nitrogen mineralization (STANFORD et al. 1973).

In soil 1 , near wilting point $\left(\mathrm{M}_{1}\right)$, a slight mobilization of nitrogen seems to have taken place, but it was not significant. By increasing the moisture the mobilization apperently became more vigorous agreeing well with the results reported by STANFord and EPSTEIn (1974). At the highest moisture level $\left(\mathrm{M}_{3}\right)$, approximating the field capacity, some losses of nitrogen did occur. The significant difference observed between moisture levels $M_{2}$ and $M_{3}$ at nitrogen level $\mathrm{N}_{2}$ can hardly be explained by the different amounts of nitrogen contained by the plant roots, since it would assume strong negative correlation between 
the amounts of nitrogen contained in the roots and those in the tops, which is not likely. Denitrification is more probable. According to STANFord and EPSTEIN this really is possible at moistures near field capasity $\left(M_{3}\right)$. The differences observed in soil 2 may well be explained by the different amounts of nitrogen contained in the roots. There is no reason to assume that mobilization had not taken place in this soil, but because of the lower content of mineralizable organic matter the amounts of mobilized nitrogen must have been smaller than in soil 1 , and so the possible differences between the treatments have probably been hidden behind the experimental error.

The soil $\mathrm{pH}$ and the nitrate nitrogen content of the soil at the end of the experiment are rather closely correlated, $r=-0.97 * * *$ for soil 1 and $r=$ $-0.98^{* * *}$ for soil 2 , as calculated from the treatment means presented in Table 5. As the uptake of nitrate was abundant, indicated here by the low nitrate content of the soil at the end of the experiment, the uptake of anions was to such an extent dominating compared with the cation uptake that the acidity of the soil decreased.

\section{REFERENCES}

CANTliffe, D. J. 1973. Nitrate accumulation in table beets and spinach as affected by nitrogen, phosphorus, and potassium nutrition and light intensity. Agron. J. 65: 563-565.

LAWRENCE, T., WARder, F. G. \& AshFord, R. 1968. Nitrate accumulation in intermediate wheatgrass. Can. J. Plant Sci. 48: 85-88.

StANFORD, G. \& EpStein, E. 1974. Nitrogen mineralization - water relations in soils. Soil Sci. Soc. Amer. Proc. 38: 103-107.

- -, Frere, M. H. \& Schwaninger, D. E. 1973. Temperature coefficient of soil nitrogen mineralization. Soil Sci. 115: $321-323$. 


\title{
Maan kosteuden vaikutus italialaisen raiheinän (Lolium multiflorum Lam.) kykyyn vähentää maan haitallisen suurta nitraattitypen pitoisuutta.
}

\author{
ANTTI JAAKKOLA ${ }^{1}$ ) \\ Yliopiston maanviljelyskemian laitos, Helsinki
}

Italialaisen raiheinän (Lolium multiflorum) suorittaman typenoton vaikutusta maan haitallisen suuren mineraali- ja varsinkin nitraattitypen pitoisuuden vähentäjänä tutkittiin astiakokeessa kasvihuoneessa. Raiheinästä korjattiin 205 päivän aikana 5 satoa, joiden kokonaistypen ja nitraattitypen pitoisuudet määritettiin. Koemaina oli hieta ja erittäin runsasmultainen hiesusavi. Niitä pidettiin kokeen ajan kolmesta eri kosteustilassa, jotka vastasivat suunnilleen pF-arvoja 2, 3 ja 4. Koe suoritettiin kahdella typpitasolla, jotka saatiin aikaan lisäämällä maihin kokeen alussa 175 ja $350 \mathrm{mg} / \mathrm{kg}$ typpeä ammoniumnitraattina.

Savimaassa, joka sisälsi alunperin nitraattityppeä $370 \mathrm{mg} / \mathrm{kg}$, jo kaksi raiheinäsatoa riitti vähentämään maan käyttökelpoista typpeä niin paljon että kasviaineksen nitraattipitoisuus, joka alunperin oli hyvin korkea, laski alle $2 \mathrm{mg} / \mathrm{g}$, silloin kun maata pidettiin kosteudeltaan kenttäkapasiteetissa. Pidettäessã maata lähellä lakastumisrajaa ei sen mineraalityppivarasto juuri vähentynyt. Maan kosteuden ollessa näiden kosteustilojen puolessa välissä, kasviaineksen nitraatinpitoisuus laski alle mainitun rajan ensi kerran kolmannessa sadossa alemmalla typpitasolla ja neljännessä sadossa korkeammalla typpitasolla.

Hietamaassa, joka sisälsi alunperin $780 \mathrm{mg} / \mathrm{kg}$ nitraattityppeä, raiheinän nitraattitypen pitoisuus laski alle mainitun rajan vasta viimeisessä sadossa, silloin kun maa oli kosteudeltaan lähellä kenttäkapasiteettia, ja vain alemmalla typpitasolla. Muissa tapauksissa kasviaineksen nitraatinpitoisuus pysyi korkeana kokeen loppuun saakka.

1) Nykyinen osoite: Maatalouden tutkimuskeskus. Maanviljelyskemian ja -fysiikan laitos. Tikkurila. 